\title{
NÁLEZ PRAVEKEJ MINIATÚRNEJ NÁDOBY V ZEMNICI NA VČASNOSTREDOVEKOM HRADISKU VALY V BOJNEJ ${ }^{1}$
}

\author{
Miriam Jakubčinová
}

DOI: https://doi.org/10.31577/szausav.2019.suppl.1.15

Keywords: Slovakia, Bojná, hillfort, Early Middle Ages, miniature clay vessel, antique

Finding of a prehistoric miniature vessel in the pit-house at the early medieval hillfort Valy in Bojná

Several dug dwelling features were unearthed during the research excavation at the hillfort Valy in Bojná. Miniature clay vessel from the Bronze Age was discovered in one of them, situated in the middle of the hillfort. Finding is remarkable from various points of view, as it was obviously antique already in the Early Middle Ages. It is certainly hard to identify who was its owner but it is possible to consider its use in the examined period. Did it belong to a collector of rare curiosities or to a child who found it and used it as a toy? Or did it have purely practical use, thus had it been used in household for storage of scarcer ingredients? It is interesting to examine also other artefacts from older periods, which were discovered at the hillfort, from the perspective of this finding.

\section{ÚVOD}

Včasnostredoveké hradisko Valy situované v katastri obce Bojná sa nachádza v juhovýchodnej časti pohoria Považský Inovec, ktoré oddeluje Považie od Ponitria. V katastri obce sa okrem hradiska Valy nachádza niekol'ko d’alších polôh (obr. 1), ktorých osídlenie možno zaradit do viacerých období (Pieta 2015, 10, obr. 1). Terénny archeologický výskum na hradisku Valy sa realizuje nepretržite už od roku 2007. Počas jednotlivých výskumných sezón bola zatial' prebádaná len čast’ areálu lokality, odkrylo sa však viacero zahĺbených (obytných aj sídliskových) objektov či nadzemných stavieb (Jakubčinová/Vanglová 2015, tabela 2; Pieta a i., v tlači).

\section{OPIS NÁLEZOVEJ SITUÁCIE A OPIS NÁLEZU}

Na konci výskumnej sezóny v roku 2015 bola v centrálnom priestore hradiska v sonde XLII zistená zemnica, ktorej väčšia čast̉ bola preskúmaná počas nasledujúcej sezóny v roku 2016. Zemnica 10 má kvadratický pôdorys s rozmermi približne 3,0 × 2,5 m (obr. 2). Kamenná pec $(0,95$ x 0,95 m) bola umiestnená v juhovýchodnom rohu a v strede pri západnej a južnej stene boli kolové jamy. Predpokladaný vchod do objektu sa zrejme nachádzal oproti kamennej peci, teda v juhozápadnom rohu. Výplň zásypu objektu tvorila zväčša svetlohnedá vrstva zeminy s prímesou drobných kamienkov, pred pecou a na dne objektu bola vrstva výrazne hnedočierna, s prímesou uhlíkov. Takmer na úplnom dne objektu, v blízkosti kolovej jamy pri západnej stene, sa našla miniatúrna nádoba. Ďalšie nálezy pochádzajúce zo zásypu objektu sú: keramika - fragmenty hlinených nádob ozdobených vlnovkou a vodorovnými líniami, stredne vel'ká železná pracka kvadratického tvaru s jedným tŕňom, neúplná železná ataša, uhlíky, archeobotanické vzorky a mazanica.

\footnotetext{
Príspevok vznikol v rámci grantového projektu 2/0001/18 agentúry VEGA a s podporou projektu APVV-14-0842.
} 


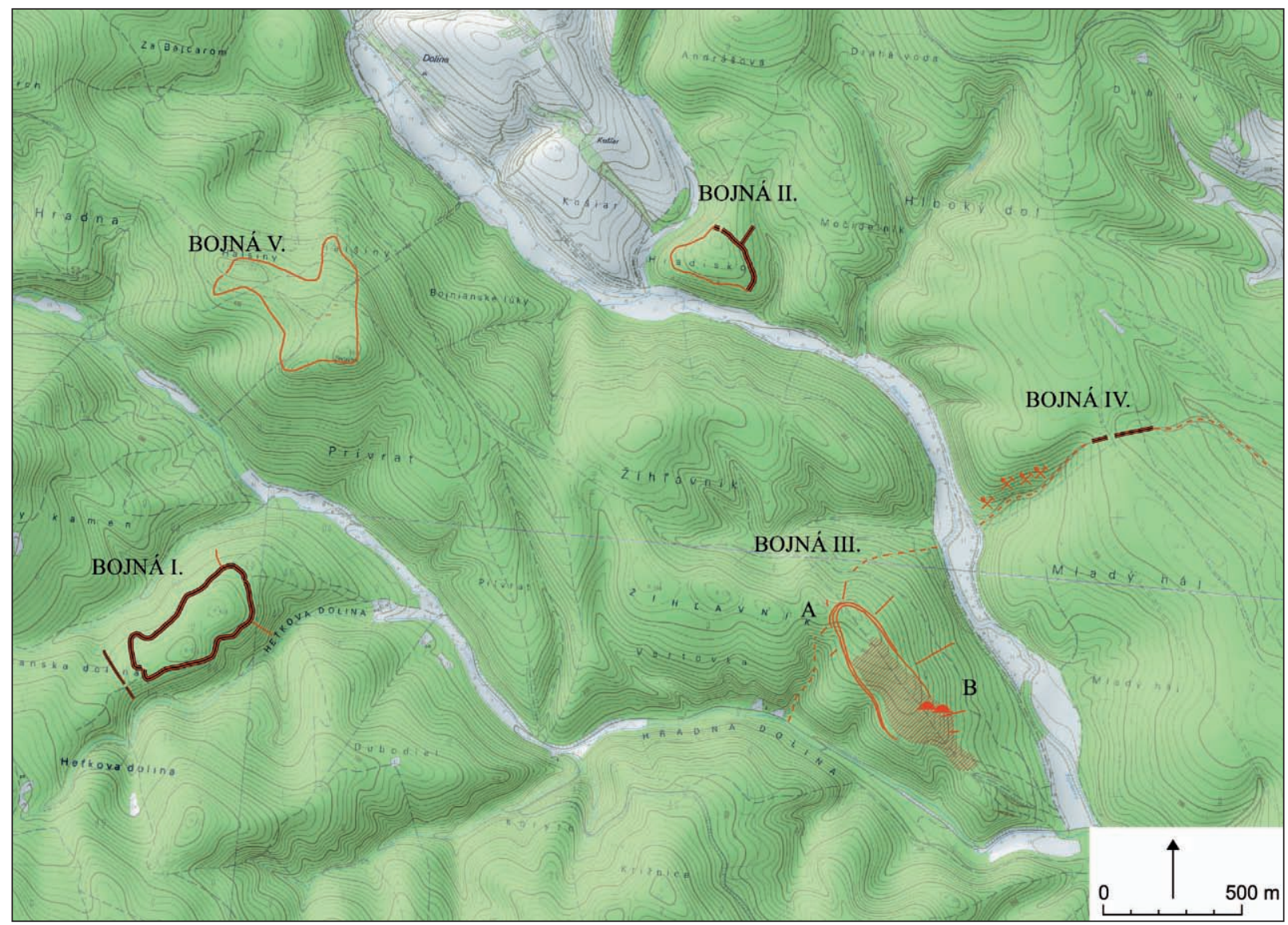

Obr. 1. Bojná, lokality v katastri obce Bojná. Bojná I-Valy, Bojná II-Hradisko, Bojná III-Žihlavník, Bojná IV-Mladý háj, Bojná V-Halšiny (zameranie lokalít M. Bartík a E. Blažová; podla Pieta 2015, obr. 1).

Miniatúrna nádoba (obr. 3) má maximálnu zachovanú výšku 31 mm, maximálnu šírku vydutiny 37 $\mathrm{mm}$, zachovanú šírku otvoru $23 \mathrm{~mm}$, hrúbku steny $0,4 \mathrm{~mm}$. Na jednej strane má stopy po odlomenom ušku s odtlačkom po vpichu, čo slúžilo zrejme na lepšie upevnenie uška na nádobu. Uško, ktoré sa nezachovalo, bolo upevnené na najväčšej vydutine nádoby a pod miernym odsadením, zužujúcim sa zrejme $\mathrm{k}$ hrdlu. Okraj nádoby je poškodený, preto je problematické určit presný tvar. Ide pravdepodobne o malú amforu (s jedným uškom) alebo šálku. Nález je možné rámcovo datovat do doby bronzovej.

Praveká miniatúrna nádoba z Bojnej nájdená vo včasnostredovekom kontexte predstavuje zrejme zberatel'ský artefakt. Tie sa zväčša nachádzajú uložené v hrobe ako sprievodné milodary, ale ojedinele sa objavia aj na sídliskách či hradiskách. Na využitie tejto miniatúry sa možno pozerat’ z dvoch hladísk: ako na funkčnú nádobu, prípadne ako na starožitnost.

\section{MINIATÚRNA NÁDOBA}

\section{Definícia}

Miniatúrne keramické nádoby nepatrili k vel’mi rozšíreným artefaktom vo včasnom stredoveku. Na území Slovenska (aj v okolitých krajinách) sa však vyskytujú v rôznych obdobiach už od neolitu. Pokial' ide o ich celkovú výšku, priemer ústia, ako aj použitie či význam, ich presná klasifikácia nie je jednoznačná. $\mathrm{V}$ princípe sú to velmi malé hlinené nádoby, ktoré sa len svojou vel'kostou odchylujú od všeobecne rozšírených tvarov keramiky, aj ked’ tvarom často kopírujú svoje väčšie predlohy (Zeman 2016, 207).

Odborníci spracovávajúci rôzne obdobia sa k týmto artefaktom stavajú rozdielne, čo si priblížime $\mathrm{v}$ nasledujúcich riadkoch.

V dobe bronzovej patrili miniatúrne nádoby $\mathrm{k}$ bežne rozšíreným typom nielen na pohrebiskách, ale aj na sídliskách. V. Mitáš (2015, 222, 223, obr. 212) ich na základe štúdia vybraných nálezov kultúr juhový- 
chodných popolnicových polí definuje ako nádoby výrazne menších rozmerov na rozdiel od štandardných typov, ktoré sú často pomerne hrubé, akoby zle opracované. Nemajú presné typologické označenie, keďže ide v podstate o zmenšené modely bežne sa vyskytujúcich tvarov. Podobne L. Olexa a T. Nováček (2013, 15-32) pri spracovaní pohrebiska z Nižnej Myšle nevyčlenili samostatnú skupinu pre tieto nádoby, aj ked’ sú na lokalite zastúpené (zvyčajne v detských hroboch). O. Chvojka $(2009,65)$ pri spracovaní keramiky mladšej a neskorej doby bronzovej z územia južných Čiech konštatuje, že miniatúrne nádoby patria skôr k tenkostennej keramike s kvalitnejším výpalom a často sú vyrobené z jemne plavenej hliny.

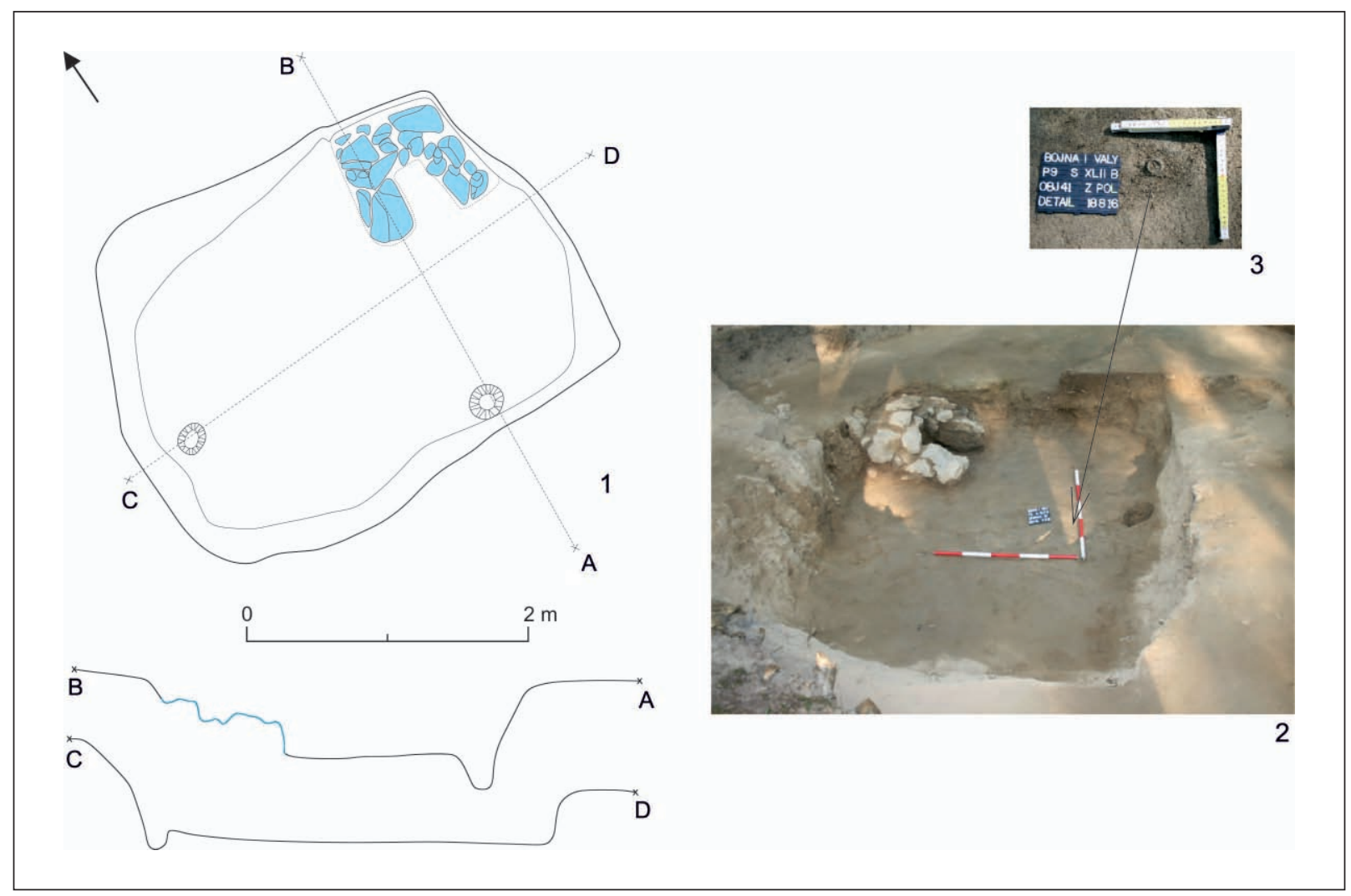

Obr. 2. Bojná I-Valy, zemnica 10. 1 - pôdorys objektu; 2 - pohlad na zemnicu zo severozápadu; 3 - detail nádoby pri objavení.

Detailnejšie sa týmto artefaktom venovali bádatelia spracovávajúci nálezy z doby rímskej. T. Zeman $(2016,207)$ pri spracovaní nálezov z juhovýchodnej Moravy vyčlenil ako miniatúrne nádoby tie, ktoré mali výšku maximálne do $70 \mathrm{~mm}$ a priemer okraja asi $90 \mathrm{~mm}$. E. Krekovič $(2014,444)$ sem zaradil nezdobené nádoby s výškou a priemerom ústia zriedka prekračujúcimi $60 \mathrm{~mm}$, ktoré sú skôr hrubostenné, nedbalo opracované a slabo vypálené.

V období včasného stredoveku sa keramika delí zväčša na tri skupiny:

- nízke - do $100 \mathrm{~mm}{ }^{2}$

- stredne vysoké - 101-150 mm;

- vysoké - nad 151 mm (Hanuliak 2004b, 184).

V rámci skupiny nízkych nádob však nie sú stanovené presnejšie kritériá pre ohraničenie kategórie miniatúrnych nádob (ked’že ide skôr o vzácne kusy). G. Fusek $(1994,77)$ pri spracovaní včasnoslovanského materiálu zo Slovenska do tejto skupiny zaraduje nádoby vysoké maximálne $80 \mathrm{~mm}$, ktoré svojím tvarom zodpovedajú bežne rozšíreným typom riadu. N. Profantová $(2005,161)$ vychádzajúc z keramiky z lokality Roztoky u Prahy k miniatúrnym nádobám zaradila exempláre tvarovo napodobňujúce väšsie typy, ale s výškou pohybujúcou sa maximálne do $90 \mathrm{~mm}$. Pri hodnotení terminológie kuchynskej keramiky D. Frolíková-Kaliszová $(2009,97)$ uvádza, že „pod pojmem hrneček si představíme malý hrníček do dětské ručky..." a „u slovanské keramiky by bylo možno zdrobnělinu použít pro miniaturní nádoby“. Pri hodnotení

\footnotetext{
V tejto kategórii ide zväčša o nádoby s výškou medzi 80-100 mm a len výnimočne tu nájdeme aj menšie exempláre.
} 
objemu nádob ich však presnejšie nešpecifikuje a zaraduje ich do skupiny malých nádob s obsahom do 1 litra.

Jednotliví bádatelia sa zväčša zhodujú, že miniatúry predstavujú prevažne tvary štandardných typov nádob bežne používaných $\mathrm{v}$ domácnosti, avšak presnejšie kritériá pre tento typ nádob sa rôznia.

\section{Použitie}

Téme miniatúrnych nádob v období včasného stredoveku sa nikto špeciálne nevenoval, a preto nie je ani jasne špecifikované, ktoré nádoby do tejto kategórie spadajú. V literatúre môžeme natrafit na malé nádoby rôznej výšky, avšak najmenšie exempláre - maximálne do $70 \mathrm{~mm}$, predstavujú rozhodne zriedkavé nálezy. Pri ich interpretácii sa bádatelia prevažne zhodujú v tom, že ide o detské hračky alebo predmety vyrobené det̉mi (Dostál 1982, 149; Eisner 1966, 296; Hanuliak 2005, 74; Váňa 1968, 134, 135; Vendtová 1969, 201). Na Slovensku sa našli napríklad na pohrebisku v Devínskej Novej Vsi, kde ich autor interpretuje ako detské hračky, ale pri nádobe nájdenej v ženskom hrobe konštatuje, že by mohlo íst’ o milodar dietata mŕtvej matke (Eisner 1952, tab. 5: 3, 23: 3, 27: 1; 1966, 296). Ďalšie nádoby sa ojedinele našli v Kútoch (Kraskovská 1947, 161, tab. I: 8), vo Vysokej pri Morave (Kraskovská 1957, 10, obr. 2), v Nitre na Školskej ulici (Ruttkay/Ruttkayová 2018, obr. 6: 1). Pri spracovaní vel'komoravských pohrebísk M. Hanuliak (2005, 73, 74) zistil niekol'ko netradičných foriem hlinených nádob, pričom miniatúrne nádoby označuje za detskú hračku, prípadne nádobu na prikrmovanie dietata. Na pohrebiskách z obdobia avarského kaganátu a Vel'kej Moravy ide vo viacerých prípadoch o nálezy zväšša z detských a ženských hrobov, napríklad v Štúrove (Točík 1968b, tab. XLI: 13), v Holiaroch (Točík 1968a, tab. LXIV: 30; LXV: 19; LXVI: 19; LXVIII: 20; LXXVIII: 12), v Radvani pri Dunaji (Točík 1992, obr. 35: 20), v Pobedime (Bialeková 1993, obr. 9: 4). Ojedinele sa nachádzajú aj na sídliskách a v zásypoch objektov, napríklad v Mužle-Čenkove (Hanuliak/Turčan 1993, 77, tab. 42: 4; 99: 3; tabela 10), prípadne v Pobedime (Vendtová 1969, 201). Miniatúrne nádoby z Mužle-Čenkova interpretovali autori $v$ jednom prípade ako detskú hračku, zatial' čo v druhom prípade vd’aka tvaru uvažovali nad použitím nádoby ako odmerky (Hanuliak/Turčan 1993, 77, tabela 10). V. Vendtová $(1969,201)$ interpretuje miniatúrne nádoby ako hračky, prípadne solničky.

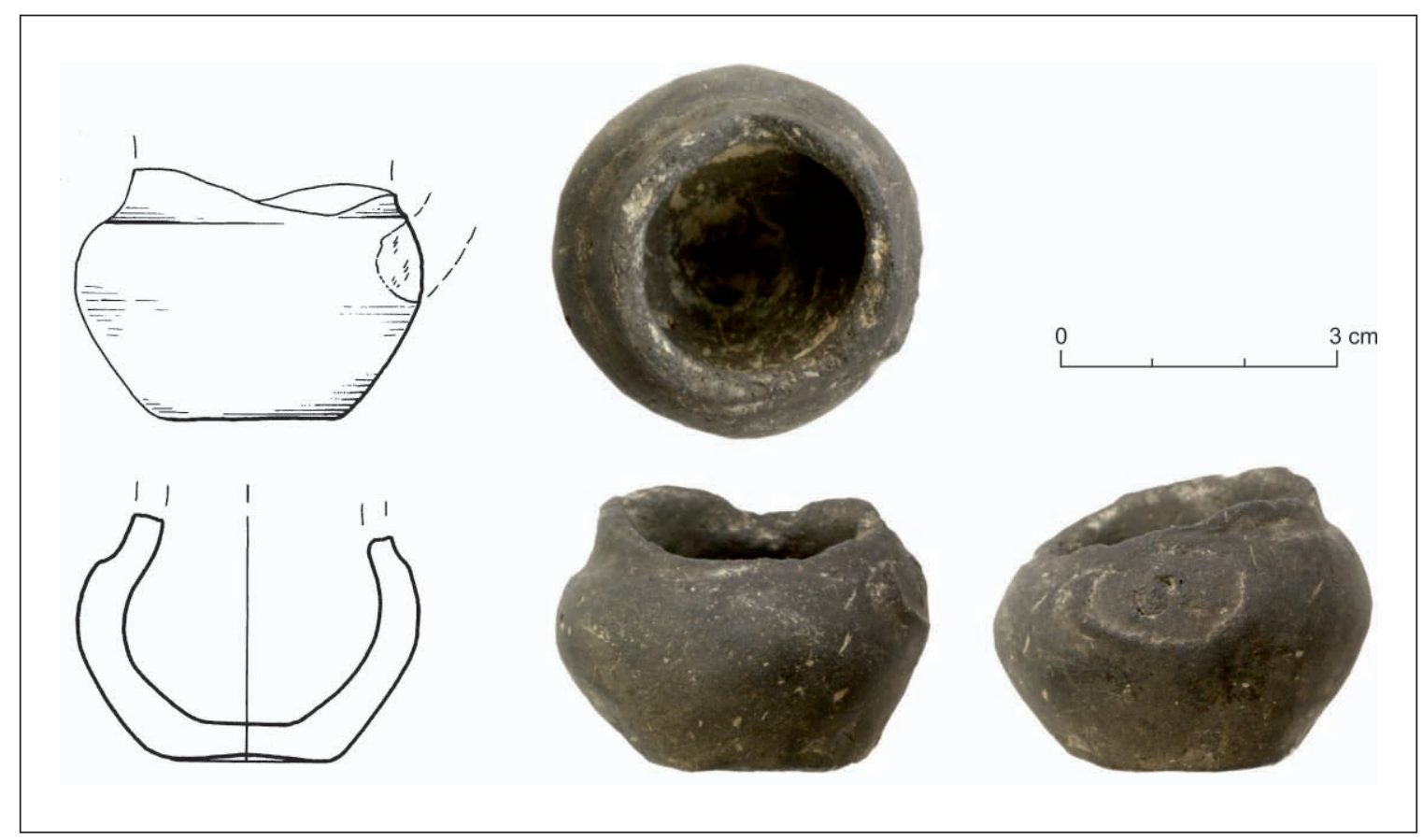

Obr. 3. Bojná I-Valy, miniatúrna nádoba (kresba N. Vaššová, foto M. Jakubčinová).

B. Dostál $(1982,187)$ nálezy z Břeclavi-Pohanska uvádza bud’ ako rituálne nádoby, alebo ako detské hračky, prípadne ako predmety spájajúce sa so životom pochovaných detí. Dve nádoby z hradiska Stará Kouřim sa interpretujú $v$ jednom prípade ako detská hračka (našla sa pri nohách dietata) a v druhom ako dodatočný milodar mŕtvemu (Šolle 1959, 465). Miniatúry - napodobňujúce misky - sa našli aj v síd- 
liskovej vrstve na hradisku Vlastislav a Z. Ván̆a $(1968,134,135)$ ich kvôli svojej jednoduchosti uvádza ako výrobky detí, a teda zároveň ako detské hračky. B. Novotný (1966, 660, 683, obr. 17) im prikladal skôr votívny charakter, podobne ako d’alším miniatúrnym artefaktom z Mikulčíc.

Malé hlinené nádoby z Novgorodu z 12. až 13. stor. interpretujú B. A. Kolčin, A. S. Chorošev a V. L. Janin (1981, 122, obr. 61) ako nádoby na uloženie farbív (v niektorých sa na dne našli zvyšky farby), hoci konštatujú, že v domácnosti mohli slúžit aj na odkladanie iných látok, napríklad mastí alebo liečiv. $V$. $A$. Baskova $(2015,52,53)$ zmenšené modely hlinených nádob z Vologdy, z obdobia od konca 15. až do 19. stor., zaraduje do skupiny hračiek - imitácií nádob z bežného života dospelých.

Z doby bronzovej poznáme množstvo miniatúrnych hlinených artefaktov, medzi ktorými sa nachádzajú aj nádoby. Jednotliví bádatelia miniatúry zvyčajne zaraduujú medzi kultové predmety, ktoré mohli slúžit pri rôznych ceremóniách a obradoch (Bátora 2015, 53-56). Na rozdiel do ostatných predmetov, miniatúrne nádoby zrejme patrili k nálezom, ktoré sa spájali aj s každodenným životom, i ked’ niekedy môžu rituálne a profánne úkony splývat alebo sa navzájom prepájat’ (Furmánek 2010; Mitáš 2015, 222, 223). Na to poukazujú tiež hrobové nálezy hračiek s možným rituálnym účelom. Napríklad miniatúrne nádoby z Nižnej Myšle z detského hrobu 40, ktoré boli uložené na hlinenom vozíku, sú posudzované ako hračky s určitou kultovou symbolikou (Olexa/Nováček 2013, 32, tab. 20: hrob 40).

E. Krekovič $(2014,451)$ pri spracovaní germánskych pohrebísk predpokladá, že v detských a ženských hroboch mohli miniatúry splñat rozdielnu funkciu. Exempláre z detských hrobov interpretuje ako detské hračky alebo výrobky, ktoré boli vyhotovené priamo detmi. Artefakty zo ženských hrobov zase vysvetluje ako nádoby na kozmetické prípravky, lieky a iné liečivá či narkotiká. T. Zeman $(2016,210)$ pri spracovaní súboru z južnej Moravy z doby rímskej zistil, že sú bežné aj na sídliskách (v zásype objektov) a ide prevažne o v ruke vyrábané exempláre s nejasnou funkciou. Mohli slúžit ako schránky pre požívatiny alebo pochutiny, tégliky alebo lampičky, avšak symbolický alebo rituálny význam v sídliskovom prostredí nebolo možné zachytit.

Zaujímavostou je výskum, ktorý na neolitických miniatúrnych nádobách z Těšetic-Kyjovíc vykonali M. Králík a M. Hložek (2005-2006). Sledovaním odtlačkov prstov zistili, že ide o výrobky detí, ktoré napodobňovali zrejme predmety používané dospelými. Pri vyhodnocovaní zohladnili však aj d’alšie kritériá, ako malé rozmery nádob, ich nedokonalý a neforemný tvar, prípadne aj odtlačky nechtov vo vnútri nádob (Králík/Hložek 2005-2006, 28).

Na základe interpretácií rôznych bádatelov možno skonštatovat', že použitie miniatúrnych nádob sa dá rozdelit $\mathrm{v}$ podstate do troch hlavných okruhov:

- hračky, prípadne výrobok dietata;

- nádoby v domácnosti - slúžiace na uschovanie rôznych (možno vzácnejších) ingrediencií - koreniny, masti, liečivá, ojedinele farby;

- nádoby na rituálne účely, prípadne milodary.

\section{MINIATÚRA AKO STAROŽITNOSŤ? ÚVAHY NAD ARCHAICKÝMI PREDMETMI Z HRADISKA VALY}

Ludí odjakživa pritahovali predmety, ktoré sa vymykajú z ich zaužívaného spôsobu života a každodenných činností. Náhodne nájdené artefakty museli byt๋ zvláštne bud’ svojím tvarom, alebo farbou, možno výzdobou, ked’že upútali svojho nálezcu, a tým sa odlišovali od bežne používaných predmetov. Pre bežného človeka mohli predstavovat niečo tajuplné, nadprirodzené. Archaické predmety v období včasného stredoveku ojedinele nachádzame v hroboch ako sprievodný milodar, ktorý bud’ dali pozostalí mŕtvemu do hrobu, alebo to bola vec, ktorá patrila zosnulému už počas jeho života. Týmito artefaktmi sa v minulosti u nás zaoberali viacerí autori vo svojich štúdiách (Hanuliak 2004a; Kolník/Rejholcová 1986; Kolníková 1973; Kraskovská 1971). Venovali sa im však aj bádatelia pri spracovaní jednotlivých lokalít, predovšetkým pohrebísk (napr. Čilinská 1966, 164; Zábojník/Béreš 2016, 83, 84).

Praveké nádoby sa velmi vzácne objavujú aj na včasnostredovekých lokalitách. Na sídliskách či hradiskách je ich však tažké interpretovał ako archaický predmet na rozdiel od nálezov v hroboch, kde sa to dá zaiste jednoznačnejšie identifikovat. Miniatúrna nádoba z Bojnej bola objavená takmer na dne zemnice. V niekol'kých d’alších objektoch na hradisku Valy sa našli nádoby, avšak zo včasného stredoveku, podobne vol'ne ležiace na podlahe príbytku alebo stojace pri peci (Jakubčinová/Vanglová 2015, 79, 80). Všetky tieto objekty s nádobami poukazujú na náhly odchod jej obyvatelov, počas ktorého si ich majitelia nestihli vziat z príbytku niektoré veci, prípadne si nemohli zobrat všetko so sebou, čo je možno aj prípad tejto miniatúrnej nádoby. 
Hlinené nádoby boli bežnou hrobovou prílohou, avšak nález pravekej nádoby v mladšom hrobe možno vnímat' ako zaujímavost', pretože pozostalí si museli uvedomovat', že praveká nádoba nebola súčastou ich vtedajšej kultúry. Jeden exemplár "nádobky“3 $\mathrm{z}$ doby bronzovej sa našiel v mužskom hrobe 409 v Devínskej Novej Vsi spolu s nožom a fragmentmi vedra (Eisner 1952, 94, 238). Praveká nádoba s jedným uškom pochádza z hrobu 177 na pohrebisku v Pilismarót-Basaharc, kde bola uložená pri lavej nohe mŕtvej ženy (Fettich 1965, 59, 60, obr. 98: 16). Staršie (praveké alebo včasnohistorické) nádoby vo včasnostredovekých hroboch mohli predstavovat’ aj predmety vykopané priamo na mieste pohrebiska pri híbení hrobu, kde už existovalo staršie osídlenie alebo hroby. Do hrobu boli následne vložené azda na základe určitej piety (Kraskovská 1971, 127, 128). ${ }^{4}$ Nemožno ešte nespomenút pyxidu zo slonoviny z neskorej doby rímskej pochádzajúcu údajne z porušeného hrobu v Ciernych Klačanoch, kde bola vraj nájdená spolu s d’alšou (pravekou) miniatúrnou nádobou ${ }^{5}$ (Kolník/Veliačik 1983, 17, 19, obr. 3; 4: 11). Častejšie sa však stretneme $\mathrm{s}$ ojedinelým črepom, niekedy perforovaným, uloženým (náhodne alebo zámerne) do hrobu, ktoré však taktiež, ako všetky kuriozity, patria k unikátnym nálezom. Napríklad perforovaný črep z terry sigillaty pochádza z hrobu 471 v Čakajovciach (Rejholcová 1995, 51, tab. LXXIV: 9), alebo črep z mladšej doby rímskej z hrobu 14/60 z Valalík-Všechsvätých (Zábojník/Béreš 2016, 22, 83). ${ }^{6}$ Okrem hlinených nádob či osamotených črepov sa výnimočne vyskytli aj sklenené nádoby, resp. ich fragmenty, ktoré boli pre l’udí vo včasnom stredoveku rovnako nevšedné (Hanuliak 2004a, 31). Znamenala praveká nádoba či črep „majetok“ mŕtveho alebo mu ju ako milodar vložil do hrobu jeho príbuzný, ktorý sa takto vzdal niečoho cenného?

Doba bronzová je na hradisku Valy zastúpená ešte fragmentom bronzového hrotu oštepu (Pieta 2015, obr. 3: 12), ktorý nepatrí medzi tradične vyhl’adávané predmety známe zo zberatel'ských aktivít človeka v období včasného stredoveku. L’udia však mali vždy tendenciu staré veci znovu využit, prípadne ich nanovo spracovat. Je to trend bežný aj v dnešnej modernej dobe, ale podobný stav bol zaiste aj vo včasnom stredoveku. Bronz bol dôležitou surovinou, ktorú bolo možné opätovne zužitkovat na výrobu nových predmetov, napríklad ozdôb, čomu muselo predchádzat jeho nové spracovanie. Fragment hrotu oštepu však mohol označovat' len zberatel'ský artefakt, rovnako ako viaceré neúplné bronzové exempláre objavené vo včasnostredovekých hroboch, často uložené v plátnovom alebo koženom vrecku zavesenom (zrejme) na opasku (Hanuliak 2004a, 26, obr. 1: 5, 9, 10, 14). Možno však symbolizoval amulet s magickým významom alebo len pozoruhodnú vec, ktorú niekto našiel a ponechal si ju.

Ako vnímat archaické predmety objavené na hradiskách a je možné ich jednoznačne interpretovat ako starožitnosti? Prečo ludia v tej dobe zbierali staršie artefakty, často aj poškodené? Chceli ich znova využit?? A mohli byt' uplatnené vo svojej primárnej funkcii alebo im bol daný druhotný účel? A je vôbec možné sa na ne pozriet podla ich predpokladaného spôsobu použitia? V nedávnej dobe sa takýmto exemplárom podrobne venoval Š. Ungerman (2009, 238), vychádzajúc z práce A. Mehlingovej (1998), ktorá rozdelila archaické predmety nájdené $\mathrm{v}$ merovejských hroboch podla spôsobu využitia do štyroch skupín:

- opätovné využitie (bud’ na pôvodný alebo sekundárny účel);

- ozdoba;

- zberatelský artefakt;

- magické vlastnosti - amulety.

Nálezy miniatúry hlinenej nádoby a fragmentu bronzového hrotu šípu z doby bronzovej nepredstavujú na hradisku v Bojnej ojedinelé rarity. Počas jednotlivých rokov výskumu bolo objavených niekolko artefaktov (tabela 1), ktoré patria do staršieho obdobia než je dominantné osídlenie lokality. V nedávnej dobe sa týmto predmetom z pohl'adu ich chronologického usporiadania venoval K. Pieta (2015, 10-14, obr. 3) v rámci štúdie o osídlení hradiska a jeho blízkeho okolia. Rozdelil ich podla obdobia:

- neolit/eneolit (štiepaná industria, sekeromlat, klin, hlinená nádoba);

- doba bronzová (fragment bronzového hrotu oštepu);

- doba laténska (fragment skleneného náramku);

- doba rímska (mince, neúplná bronzová spona).

\footnotetext{
V publikácii chýba vyobrazenie a presnejšie údaje, ale autor v texte spomína „nádobku“ v strede hrobu, takže sa dá predpokladat', že išlo o malý exemplár (Eisner 1952, 94).

4 Podobný názor má aj T. Trębaczkiewiczová (1963, 137, tab. I: c), ktorá takto interpretovala náhodný nález lužickej nádoby vo včasnostredovekom mužskom hrobe 34, nájdený v blízkosti l’avého lýtka mŕtveho.

5 Jednoznačné interpretovanie týchto nádob ako súčast̉ hrobovej výbavy nie je možné určit, ked’že išlo o porušený hrob, ktorý nebol správne odkrytý (Kolník/Veliačik 1983, 17).

6 Pre d’alšie lokality pozri (Ungerman 2009, 236, pozn. 7).
} 
Tieto artefakty je možné rozdelit tiež podla materiálu, z ktorého boli vyrobené:

- kamenné predmety (štiepaná industria, sekeromlat, klin);

- bronzové predmety (fragment bronzového hrotu oštepu, neúplná bronzová spona, mince);

- sklenené predmety (fragment skleneného náramku);

- hlinené predmety (nádoby).

Velmi často ide o ojedinelé artefakty pochádzajúce z rôznych období, ako napríklad fragment skleneného náramku, neúplná bronzová spona či fragment bronzového hrotu oštepu alebo minca (Pieta 2015, 13, 14, obr. 3: 11-13). Našli sa predovšetkým pri znižovaní vrstiev v jednotlivých sondách, čast’ nálezov pochádza zo zberu (hlavne kovové predmety ako minca a fragment hrotu oštepu), prípadne zo zásypu objektov alebo z ich tesnej blízkosti (miniatúrna nádoba a štiepaná industria). Sú rozptýlené po celom areáli hradiska a aj na západnom predhradí (obr. 4). Väčšia koncentrácia bola objavená na najvyššie položenom mieste, na ploche 3, kde bolo preskúmaných niekolko zahíbených obytných a sídliskových objektov, ako aj nadzemných stavieb zo včasného stredoveku. Najpočetnejšie sú na lokalite zastúpé kamené artefakty - úštepy alebo jadiá, originálny je však objav klinu a sekeromlatu.

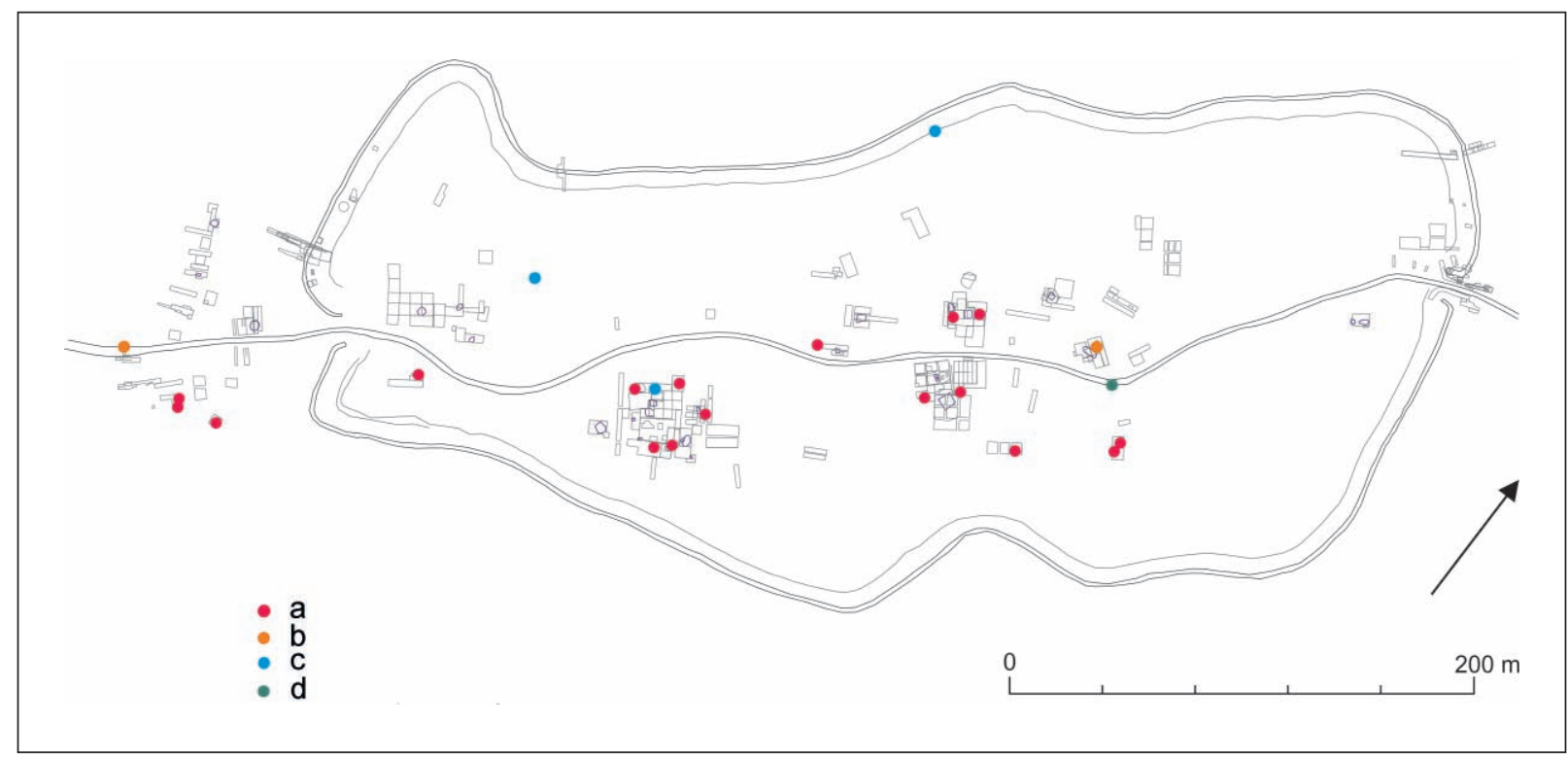

Obr. 4. Bojná I-Valy, lokalizácia jednotlivých artefaktov - starožitností - v areáli hradiska. a - kamenné predmety; b hlinené predmety; c - bronzové predmety; $\mathrm{d}$ - sklenené predmety.

Celý súbor z Bojnej predstavuje základné archaické typy, aké môžeme nájst’ aj vo včasnostredovekých hroboch, t. j. nádoby, črepy nevynímajúc (Hanuliak 2004a; Kraskovská 1971). Na zberatelskú aktivitu Slovanov môžu poukazovat predovšetkým ojedinelé predmety. Mohli ich znovu využit v základnej alebo v sekundárnej funkcii. Napríklad L'. Kraskovská $(1971,130)$ konštatovala, že spony v hroboch z obdobia avarského kaganátu boli často nájdené vo funkčnej polohe - na hrudi, prípadne pri lebke a mohli teda plnit svoju funkciu - čiže spínanie odevu, zatial' čo Z. Čilinská $(1966,164)$ ich pokladala skôr za ozdobu odevu. M. Hanuliak $(2004 a, 31)$ pri spracovaní nálezov zo včasnostredovekých pohrebísk zistil, že spony sa často nachádzali skôr v sekundárnej pozícii, a preto podla neho mali iný, skôr symbolický alebo magický význam. Spona z Bojnej je deformovaná, čiže možno skôr predpokladat, že ide o zberatel'ský kus, azda s magickým významom (?), prípadne polotovar pripravený na spracovanie. Zaiste však nevieme upresnit', či sponu pri nájdení objavili zachovanú celú, vo funkčnom stave, alebo už bola poškodená. 
Tabela 1. Bojná I-Valy. Súpis a nálezové okolnosti archaických artefaktov objavených na hradisku do roku 2016.

\begin{tabular}{|c|c|c|c|c|c|c|c|}
\hline por. č. & rok & prír. č. & názov predmetu & surovina & plocha/sektor/sonda & kontext & dátum \\
\hline 1 & 2004 & 67 & $\begin{array}{l}\text { kosáková čepel' } \\
\text { zo silicitu }\end{array}$ & kameň & $\begin{array}{l}\text { západné predhradie, sonda } \\
\text { V/2004 }\end{array}$ & vrstva & 12. 10. 2004 \\
\hline 2 & 2006 & bez čísla & $\begin{array}{l}\text { "minca (Constantinus I.) } \\
\text { č. mince } 9131 \text { " }\end{array}$ & bronz & plocha hradiska & zber & 1. 5.2006 \\
\hline 3 & 2006 & bez čisla & $\begin{array}{l}\text { "minca (Jovianus ) č. } \\
\text { mince 9036" }\end{array}$ & bronz & plocha hradiska & zber & 1. 1. 2006 \\
\hline 4 & 2007 & 180 & $\begin{array}{l}\text { fragment jadra } \\
\text { z rádiolaritu }\end{array}$ & kameň & $\begin{array}{l}\text { plocha } 3 \text {, sektor IX-D/16a, } \\
\text { S XII/c }\end{array}$ & K 12, zber & 18. 7. 2007 \\
\hline 5 & 2007 & 1100 & jadro zo silicitu & kameň & $\begin{array}{l}\text { plocha } 5 \text {, sektor VI- } \\
\text { D/22a-d, S X/c/2007 }\end{array}$ & K 123.1 & 11. 9. 2007 \\
\hline 6 & 2008 & 1 & čepel' z limnosilicitu & kameň & plocha hradiska & zber & 4. 6.2008 \\
\hline 7 & 2008 & 197 & spona & bronz & $\begin{array}{l}\text { "plocha 3, sektor IX-D/8c, } \\
13 a, \text { S XI/a/2008“" }\end{array}$ & K 172.1 & 16. 7. 2008 \\
\hline 8 & 2008 & 217 & čast' čepele z rádiolaritu & kameň & $\begin{array}{l}\text { „plocha 3, sektor IX-D/14a, } \\
9 \mathrm{c}, \mathrm{S} \times \mathrm{II} / \mathrm{b} / 2008 \text { “ }\end{array}$ & K 174.1 & 21. 7.2008 \\
\hline 9 & 2008 & 408 & $\begin{array}{l}\text { fragment jadra z } \\
\text { obsidiánu }\end{array}$ & kameň & $\begin{array}{l}\text { plocha } 8, \text { sektor } V-D / 17 d \\
18 c, 22 a, d, 23 c, b, S \\
\text { XVI/2008 }\end{array}$ & K 2.38 & 6. 8. 2008 \\
\hline 10 & 2008 & 552 & jadro z obsidiánu & kameň & $\begin{array}{l}\text { plocha } 8 \text {, sektor } V-D / 17 d \text {, } \\
18 c, 22 a, d, 23 c, b, S \\
X V I / 2008\end{array}$ & K 1.1 & 1. 8.2008 \\
\hline 11 & 2008 & 745 & $\begin{array}{l}\text { "sekeromlat z granitu až } \\
\text { granodioritu“ }\end{array}$ & kameň & $\begin{array}{l}\text { „plocha 3, sektor IX-D/22c, } \\
\text { sonda XIV/a/2008“ }\end{array}$ & K 292.1 & 16. 10. 2008 \\
\hline 12 & 2009 & 20 & čepel' zo silicitu & kameň & $\begin{array}{l}\text { „plocha } 5 \text {, sektor VI-D/9d } \\
(10-15 \mathrm{~m}), \text { sonda III/c“ }\end{array}$ & K 150.5 & 7. 7. 2009 \\
\hline 13 & 2009 & 78 & $\begin{array}{l}\text { čast' čepiel'ky z } \\
\text { obsidiánu }\end{array}$ & kameň & $\begin{array}{l}\text { plocha } 3 \text {, sektor IX-D/22d, } \\
23 \mathrm{c} \text {, sonda II/a }\end{array}$ & K 324.1 & 14. 7. 2009 \\
\hline 14 & 2009 & 131 & klin z prachovca & kameň & $\begin{array}{l}\text { plocha } 10 \text {, sektor XI-D/13a, } \\
\text { b, sonda VIII/b }\end{array}$ & K 1.17 & 16. 7. 2009 \\
\hline 15 & 2009 & 422 & čast' čepele $z$ rádiolaritu & kameň & $\begin{array}{l}\text { „plocha } 7 \text {, sektor VI-C/20c, } \\
\text { rušenie kontrolného bloku } \\
\text { v K 205, výplň zemnice } 5 “\end{array}$ & K 205 & 18. 8. 2009 \\
\hline 16 & 2009 & 493 & čepel' dýky & bronz & $\begin{array}{l}\text { plocha hradiska, sektor } \\
\text { X-C/13a }\end{array}$ & zber K 0.177 & 11. 9. 2009 \\
\hline 17 & 2009 & 519 & úštep z rádiolaritu & kameň & $\begin{array}{l}\text { plocha } 7 \text {, sektor IV/E, VI- } \\
\text { C/19d, 20c, } 24 b, 25 a\end{array}$ & $\begin{array}{l}\text { „K } 224.1 \\
(\mathrm{hI} .30 \mathrm{~cm})^{\prime}\end{array}$ & 16. 9.2009 \\
\hline 18 & 2009 & 389 & $\begin{array}{l}\text { fragmenty pravekej } \\
\text { nádoby }\end{array}$ & hlina & $\begin{array}{l}\text { plocha } 6 \text {, rez cez cestu, } \\
\text { sektor XIV-D/1d, 6a, sonda } \\
\text { VI/c/2008, západný profil }\end{array}$ & hí. 50 cm & 25. 8. 2009 \\
\hline 19 & 2011 & 141 & $\begin{array}{l}\text { „čepel' z rádiolaritu až } \\
\text { rohovca“ }\end{array}$ & kameň & $\begin{array}{l}\text { plocha 3, sektor I/I, IX- } \\
\text { D/7a, c, 12a }\end{array}$ & K 470.5 & 6. 8. 2011 \\
\hline 20 & 2012 & 483 & fragment náramku & sklo & $\begin{array}{l}\text { „plocha hradiska, cesta } \\
\text { nad plochou } 8 \text {, sektor } \\
\text { V-D/8a, b“ }\end{array}$ & zber & 20. 9. 2012 \\
\hline 21 & 2013 & 33 & $\begin{array}{l}\text { "minca (Constans/ } \\
\text { Constantius/Constantius } \\
\text { Gallus)“ }\end{array}$ & bronz & $\begin{array}{l}\text { vnútorná strana hradiska, } \\
\text { priekopa pri severnom } \\
\text { vale, sektor VII-B/7a }\end{array}$ & zber & 9. 7.2013 \\
\hline 22 & 2013 & 272 & $\begin{array}{l}\text { „Čepel'ové škrabadlo } \\
\text { z limnosilicitu“ }\end{array}$ & kameň & $\begin{array}{l}\text { „plocha } 7 \text {, sektor VII-C, } \\
\text { D/21d, 1a sonda XXX/a“ }\end{array}$ & $\begin{array}{l}\text { „K } 275 \\
(10-12 \mathrm{~m}) “\end{array}$ & 13. 8. 2013 \\
\hline 23 & 2015 & 20 & industria štiepaná & kameň & $\begin{array}{l}\text { "plocha } 5 \text {, sektor VII-D/6c, } \\
\text { d 11a, b sonda XXXIV/i“" }\end{array}$ & K 252 & 27. 7. 2015 \\
\hline 24 & 2016 & 43 & miniatúra nádoby & hlina & $\begin{array}{l}\text { „plocha } 9 \text {, sektor V-C, } \\
\text { D/23d, } 3 b \text {, d,sonda XLII/b, } \\
\text { objekt } 41 \text { (Z polovica)“ }\end{array}$ & K 99 & 18. 8. 2016 \\
\hline 25 & 2018 & 53 & industria štiepaná & kameň & $\begin{array}{l}\text { západné predhradie, } \\
\text { sektor XIII-D/18b, 19a, } \\
\text { sonda LVIII }\end{array}$ & K 169 & 24. 7. 2018 \\
\hline 26 & 2018 & 71 & industria štiepaná & kameň & $\begin{array}{l}\text { západné predhradie, } \\
\text { sektor XIII-D/18b, 19a, } \\
\text { sonda LVIII/b }\end{array}$ & K 169 & 15. 8. 2018 \\
\hline
\end{tabular}

Podobne aj mince $\mathrm{v}$ hroboch nachádzame najčastejšie $\mathrm{v}$ dvoch odlišných pozíciách - ako súčast̉ náhrdelníka, resp. ozdoby krku, prípadne prišité na odeve (perforované kusy), alebo uložené vo vrecku zavesenom na opasku, možno ako amulet alebo zberatel'ský predmet (Kraskovská 1971, 130). V oboch prípadoch však mohli spĺňat aj rituálny či magický účel, pretože niektorí ludia (skôr deti, prípadne ženy) ich nosili ako ozdobu na krku alebo šatách a iní (pravdepodobne muži) ich zase mali odložené vo vrecku 
zavesenom na opasku (Ungerman 2009, 243). Portrét na minciach zrejme pre Slovanov neznamenal nejakú konkrétnu osobu, prípadne nebol pripomienkou doby rímskej, ale zastupoval skôr mýtickú postavu alebo nejakého boha, a práve tým boli mince pre nich výnimočné a nosili ich aj napriek tomu, že už razba bola málo viditelná (Ungerman 2009, 248). Mince z Bojnej reprezentujú exempláre, ktoré majú razbu ošúchanú tak vel’mi, že je až tažko čitatelná a sú bez prerazeného otvoru na zavesenie, čiže neslúžili ako prívesok. E. Kolníková $(1973,132)$ sa domnieva, že mince s takto deformovanou razbou svedčia o ich častom používaní, čiže slúžili ako amulety s magickou funkciou, a zväčša boli schované vo vrecku. Na základe týchto informácií je teda možné sa domnievat', že mince z Bojnej patrili skôr mužom.

Magický význam zrejme vyjadrovali aj fragmenty laténskych sklenených náramkov, predovšetkým modrej farby. Ich oblúbenost’ vyplývala azda z toho, že mali „farbu neba“, s čím sa mohla spájał aj viera v ich údajne „čarovnú moc" (Ungerman 2009, 242, 243). Objavujú sa v hroboch, často spolu s inými predmetmi na jednom mieste, akoby uložené v organickom vrecku na opasku (Hanuliak 2004a, 31; Kraskovská 1971, 129). Ich výskyt na hradiskách či sídliskách, bez sprievodného keramického materiálu, je považovaný za svedectvo o náhodných nálezoch (Meduna 1997, 256).

Poslednú skupinu predstavuje štiepaná a brúsená industria, ktorú bádatelia zvyčajne nezaradujú medzi starožitnosti. Štiepaná industria sa často vyskytuje vo včasnostredovekých hroboch ako súčast’ kresadla namiesto kresacích kameňov, ${ }^{7}$ ale obvyklé sú aj na hradiskách. Ide o rôzne druhy, prevláda však silicit (nielen z miestnych zdrojov), limnosilicit a rohovec. Nejde pritom len o čepele či úštepy, ale aj o jadrá. Autori sa zhodujú na tom, že to sú praveké nálezy, ktoré pochádzajú bud' z blízkeho okolia lokality, alebo aj priamo z nich, ak boli dlhodobejšie osídlené. ${ }^{8}$ Boli zrejme náhodne nájdené a druhotne využité pri príprave ohňa. V hroboch sa často našli na jednom mieste spolu s inými predmetmi, zväčša v oblasti panvy, akiste uložené v koženom alebo plátnovom (organickom) vrecku (Hanuliak 2004b, 130, 131). L. Kaňáková Hladíková $(2014,205)$ tvrdí, že rôznorodost druhov štiepanej industrie na jednej lokalite môže svedčit o tzv. garbage economy, čiže zbere rozmanitých využitelných artefaktov v oblasti pravekých sídlisk, pričom každý jedinec si vyberal materiál, ako aj konkrétnu lokalitu, zaujímavý práve pre neho. Ku kamennej industrii sa však viažu aj viaceré povery (pretrvávajúce až do 20. stor.), ktoré by sa mohli spájat’ s ojedinelým výskytom týchto artefaktov na sídliskách či hradiskách z obdobia včasného stredoveku. Považovali sa za pozostatok úderu blesku, čo im dávalo magickú (ochrannú a uzdravujúcu) moc (Ungerman 2009, 241). Väčší dôraz sa kládol na predmety, ktoré mali v strede otvor slúžiaci na nasadenie poriska. Verilo sa, že boli prevŕtané bleskom, a preto boli účinnejšie v ochrane proti zlým duchom (Sklenár 1999, 24, 25). Odhliadnuc od týchto „magických predstáv a povier“ je ich ojedinelý nález možné vysvetlit jednoducho zvedavostou a záujmom o nezvyčajné predmety, ked’že takýto objav bol určite pozoruhodný a neobvyklý. Ich iné využitie predstavuje napríklad objavenie kamennej sekery v hrobe 1 vo Vel'kom Cetíne, poloha Pilišské, ktorá bola uložená pri pravej ruke muža - bojovníka s ostrohami (Ruttkay/Ruttkayová 1998, 142). Ide zaiste o kuriózny prípad, kde kamenná sekera možno predstavovala náhradu za železný exemplár (?).

Na hradisku Valy sa počas niekol'kých rokov výskumu odkrylo viacero obytných objektov, množstvo drobných predmetov (predovšetkým zo železa), ale aj vel'ký objem keramického materiálu. A aj ked' ešte celý tento bohatý keramický súbor nie je kompletne spracovaný, podarilo sa v ňom pravekú alebo včasnohistorickú keramiku zachytił zatial' len v ojedinelých prípadoch. Ide napríklad o už spomínanú miniatúru zo zemnice 10, prípadne ojedinelý črep z plochy 7,9 a jednu nádobu (neolit/eneolit) objavenú na západnom predhradí pri skúmaní rezu cez cestu..$^{10}$ Opevnenie na hradisku bolo vybudované predovšetkým z hliny pochádzajúcej priamo z areálu lokality. Na lidarových snímkach sa podarilo zachytit široký priestor vo vnútornej časti v blízkosti valu, z ktorého bola táto zemina zrejme odtažená (Ruttkay 2015, 304). Opevnenie bolo skúmané na niekolkých miestach. Keramiku a d’alšie artefakty, ktoré sa pritom získali, možno predbežne zaradit predovšetkým do včasnostredovekého obdobia. Neprítomnost’ keramického materiálu z minulých období môže poukazovat na to, že archaické predmety pochádzali

\footnotetext{
Boli objavené na Slovensku aj na Morave, napríklad na pohrebisku v Starom Měste (Hrubý 1955, 118, obr. 15), v Olomouci-Nemilanoch (Přichystal 2014, 200), v Stěbořicích (Kouřil/Tymonová 2013, 150, 151), v Hradci nad Moravicí (Kouřil 2004, 70, pozn. 19), vo Vel'kých Bílovicích (Měřínský 1985, 45, 46), v Mužle-Čenkove (Hanuliak/Kuzma 2015, 102, 103), v Skalici (Budinský-Krička 1959, 25) alebo vo Valalikoch-Všechsvätých (Zábojník/Béreš 2016, 77), ako aj na d’alších včasnostredovekých pohrebiskách, vel'mi často v hroboch mužov (Hanuliak 2004b, 130, 131, obr. 139).

8 Literatúru pozri v pozn. 7.

9 Za informáciu d’akujem kolegyni Mgr. T. Vanglovej, PhD.

10 Túto situáciu sa však podarilo v poslednom období zmenit, ked’že na západnom predhradí bolo počas výskumu v roku 2019 objavených niekol'ko pravekých črepov.
} 
skôr zo zberatelskej činnosti obyvatel’ov hradiska, a išlo teda najmä o náhodne objavené exempláre, a že lokalita nebola intenzívne osídlená v staršom období. Či boli tieto exempláre nájdené neúmyselne, alebo išlo o zámerné vyhl’adávanie iných starších lokalít je otázne, ale v blízkosti hradiska Valy sa nachádza niekol'ko významných nálezísk (napr. poloha Bojná V-Halšiny, Úhrad či Marhát), kde mohli byt̉ jednotlivé artefakty odkryté (Pieta 2015, 10-14).

\section{ZÁVER}

Nález miniatúrnej nádoby na hradisku Valy je pozoruhodný a prináša so sebou viacero otázok, ktorých odpovede sa nesú neraz $\mathrm{v}$ hypotetickej rovine. Vo včasnom stredoveku sa miniatúrne nádoby vyskytovali, ale nepatrili k rozšírenému typu nádob. Zrejme preto objav takejto miniatúry zaujal človeka (nálezcu), ktorý si ju vzal domov. Jednotliví bádatelia interpretujú funkciu miniatúrnych nádob (aj ked' z odlišných období) často podobným spôsobom - ako hračky či výrobky dietata, nádoby slúžiace na uchovávanie rôznych korenín, pochutín, mastí alebo olejov či liečiv, prípadne ako nádoby určené pre rituálne či obetné účely. Zaiste však možno súhlasit s T. Zemanom $(2016,210)$, ktorý konštatuje, že nie je možné vypracovat' všeobecné vysvetlenie pre všetky miniatúrne nádoby, ale je potrebné $\mathrm{k}$ nim pristupovat individuálne podla konkrétneho nálezového kontextu.

Miniatúrna nádoba z Bojnej patrí $\mathrm{k}$ archaickým exemplárom - starožitnostiam. Vo všeobecnosti sa tento druh artefaktov v domácnosti bud' nepoužíval vôbec, alebo len na výnimočné účely. Je možné, že podobne tomu tak mohlo byt tiež vo včasnom stredoveku, a nádoba slúžila skôr na uchovávanie vzácnejších ingrediencií v domácnosti. Možno práve preto, že išlo o netradičný artefakt objavený náhodne, mala pre človeka vyššiu hodnotu. Konkrétne ako nádoba pre majitela neoplývala zvláštnymi magickými schopnostami, ale práve neobyčajný spôsob nájdenia sa mohol spájat s určitým druhom rituálu a symbolizovat istú vzácnost'.

A komu patrila, resp. kto bol jej majitelom? Žene, dietału alebo mužovi? Priniesol nález domov muž zo svojich „potuliek“ a daroval ho žene či dietatu, alebo ide o predmet, ktorý sa dedil v rodine? Úvahy nad týmito otázkami môžu byt̉ rôzne. Exempláre vyslovene prináležiace ženám či detom na hradisku Valy nepredstavujú bohatú skupinu (časti náušníc, prasleny, ostrohy malej vel'kosti, rolničky či lunice), a oproti výstroju jazdca a bojovníka tvoria výraznú menšinu. Malé až miniatúrne hlinené nádoby sa neraz interpretujú ako hračky (deti ale mohli ako hračky používat aj predmety z menej trvácneho materiálu, ktoré sa nemuseli zachovat'). $V$ tomto prípade však nie je jednoznačné, či ide o hračku a skôr by sa o nej dalo uvažovat’ ako o nádobe využívanej v domácnosti. Žena sa vo včasnom stredoveku viaže predovšetkým s domácnostou a s výchovou detí. Ale možno túto miniatúru spájat len výlučne so ženou? Predmety dennej potreby, resp. z domácnosti, boli určite bežné nielen pre ženy, ale tiež pre mužov, hoci je zaiste jasné, že v danom období bola zretelnejšia del'ba práce na ženskú a mužskú. Napriek tomu miniatúra nemusela patrit vyslovene žene, pretože rovnako pre muža pracujúceho s hlinou - hrnčiara mohla byt jedinečnou raritou.

Nález miniatúry podnietil úvahy nad starožitnostami na hradisku Valy a potrebu znova sa pozriet aj na d’alšie podobné exempláre $z$ tejto lokality. Ich využitie mohlo byt๋ bezpochyby rôznorodé, či už na ich predurčený účel, alebo boli inak druhotne užitočné. Je možné, že v sebe sklbili aj niekol'ko funkcií, napríklad mohli slúžit ako ozdoba s určitým magickým, resp. ochranným významom (napr. minca). Rovnako však prvotná funkcia mohla odzniet' (napr. pri poškodení spony), a preto sa zmenilo aj jej postavenie a účel (zo spony sa stal polotovar alebo zberatel'ský exemplár).

Interpretovanie archaických artefaktov z Bojnej však zostáva nadalej otvorené, ked’že výskum pokračuje a aj táto hypotéza o pravdepodobných zberatelských aktivitách obyvatelov lokality by mohla byt๋ ešte ináč vysvetlená. Na stavbu valov sa využil materiál len z určitého priestoru hradiska a staršie, možno len krátkodobé, osídlenie nemuselo byt zachytené. Rovnako aj podrobné spracovanie celého keramického materiálu by mohlo priniest’ nové informácie. Neprítomnost keramiky však zatial’ poukazuje na to, že archaické predmety pochádzali pravdepodobne zo zberatel'skej činnosti. Mohlo íst' o náhodne objavené artefakty, ale taktiež o zámerné vyhl'adávanie starších lokalít, napríklad z blízkeho aj vzdialenejšieho okolia hradiska Valy. 


\section{LITERATÚRA}

Baskova 2015

Bátora 2015

Bialeková 1993

Budinský-Krička 1959

Čilinská 1966

Dostál 1982

Eisner 1952

Eisner 1966

Fettich 1965

Frolíková-Kaliszová 2009

Fusek 1994

Furmánek 2010

Hanuliak 2004a

Hanuliak $2004 b$

Hanuliak 2005

Hanuliak/Kuzma 2015

Hanuliak/Turčan 1993

Hrubý 1955

Chvojka 2009

Jakubčinová/Vanglová 2015

Kaňáková Hladíková 2014

Kolčin/Chorošev/Janin 1981

Kolník/Rejholcová 1986

Kolník/Veliačik 1983

Kolníková 1973

Kouřil 2004

Kouřil/Tymonová 2013

Kraskovská 1947

Kraskovská 1957

Kraskovská 1971

Králík/Hložek 2005-2006

Krekovič 2014
V. A. Baskova: Gliňannyje izdelija srednevekovoj Vologdy (po materialam raskopok na Kremlevskoj ploščadi. In: Meždunarodnaja polevaja škola v Bolgare. Sbornik materialov itogovoj konfederacii. Kazaň - Bolgar 2015, 51-57.

J. Bátora: Artefakty. In: V. Furmánek (zost.): Staré Slovensko 4. Doba bronzová. Nitra 2015, 41-101.

D. Bialeková: Slovanské pohrebisko v Pobedime (poloha Na laze II/71). Študijné zvesti Aú SAV 29, 1993, 179-207.

V. Budinský-Krička: Slovanské mohyly v Skalici. Bratislava 1959.

Z. Čilinská: Slawisch-awarisches Gräberfeld in Nové Zámky. Bratislava 1966.

B. Dostál: Drobná pohřebiště a rozptýlené hroby z Břeclavi-Pohanska. Sborník prací Filosofické fakulty Brněnské university E 27, 1982, 135-201.

J. Eisner: Devínska Nová Ves. Bratislava 1952.

J. Eisner: Rukovět' slovanské archeologie. Praha 1966.

N. Fettich: Das awarenzeitliche Gräberfeld von Pilismarót-Basaharc. Budapešt' 1965.

D. Frolíková-Kaliszová: Hrnce, hrnky, hrnečky. In: P. Dresler/Z. Měřínský (ed.). Archeologie doby hradištní v České a Slovenské republice. Sborník přispěvků přednesených na pracovním setkání Archeologie doby hradištní ve dnech 24.-26. 4. 2006. Brno 2009, 94-98.

G. Fusek: Slovensko vo včasnoslovanskom období. Nitra 1994.

V. Furmánek: Radzovce. Osada l’udu popolnicových polí. Nitra 2010.

M. Hanuliak: Predmety pravekej a včasnohistorickej proveniencie na vel'komoravských nekropolách z územia Slovenska. Študijné zvesti AÚ SAV 36, 2004, 25-34.

M. Hanuliak: Vel'komoravské pohrebiská. Pochovávanie v 9.-10. storočí na území Slovenska. Nitra 2004.

M. Hanuliak: Netradičné formy nádob z vel'komoravských pohrebiskových lokalít. Študijné zvesti AÚ SAV 38, 2005, 71-78.

M. Hanuliak/I. Kuzma: Mužla-Čenkov II. Osídlenie z 9.-12. storočia Nitra. 2015.

M. Hanuliak/V. Turčan: Keramické nálezy zo sídliskových objektov. In. M. Hanuliak/I. Kuzma/P. Šalkovský: Mužla-Čenkov I. Osídlenie z 9.-12. storočia Nitra. 1993, 71-86.

V. Hrubý: Staré Město. Velkomoravské pohřebiště „Na Valách“. Praha 1955.

O. Chvojka: Jižní Čechy v mladší a pozdní době bronzové. Brno 2009.

M. Jakubčinová/T. Vanglová: Príspevok k vnútornej zástavbe hradiska Bojná IValy. In: K. Pieta/Z. Robak (ed.): Bojná 2. Nové výsledky výskumu včasnostredovekých hradísk. Nitra 2015, 63-90.

L. Kaňáková Hladíková: Posudek souboru štípané industrie z pohřebiště Olomouc-Nemilany. In: R. Přichystalová/M. Kalábek (ed.): Raněstředověké pohřebiště Olomouc-Nemilany. Katalog. Brno 2014, 203-205.

B. A. Kolčin/A. S. Chorošev/V. L. Janin: Usad'ba novgorodskovo chudožnika XII v. Moskva 1981.

T. Kolník/M. Rejholcová: Rímske relikty na slovanských náleziskách a problém antických tradícií u Slovanov. Slovenská archeológia 34, 1986, 343-356.

T. Kolník/L. Veliačik: Neskoroantická pyxida z Čiernych Klačian. (Ikonografia, datovanie a vzt’ahy k Vel’kej Morave). Slovenská archeológia 31, 1983, 17-84.

E. Kolníková: K sekundárnemu používaniu rímskych mincí na Slovensku. $\mathrm{Nu}$ mismatické listy 28, 1973, 129-137.

P. Kouřil: Raně středověký bojovnický hrob z Hradce nad Moravicí. Slovenská archeológia 52, 2004, 55-76.

P. Kouřil/M. Tymonová: Slovanský kostrový mohylník ve Stěbořicích. Brno 2013.

L. Kraskovská: Zpráva o staroslovanskom nálezisku pri Kútoch. Historica Slovaca 5, 1947, 158-162.

L. Kraskovská: Slovanské nálezy z Vysokej pri Morave. Študijné zvesti AÚ SAV2, 1957, 101-104.

L. Kraskovská: Laténske a rímske relikty v slovansko-avarských hroboch na Slovensku. Sborník prací Filosofické fakulty Brněnské university E 16, 1971, 127-131. M. Králík/M. Hložek: Hodnocení otisků prstů na dvou miniaturních keramických nádobkách kultury s moravskou malovanou keramikou z Těšetic-Kyjovic. Sborník prací Filosofické fakulty Brněnské university M 10-11, 2005-2006, 21-31.

E. Krekovič: Miniaturgefässe im quadischen Kultur-gebiet in der Slowakei. In: R. Madyda-Legutko/J. Rodzińska-Nowak (red.): Honoratissimum assensus genus 
Meduna 1997

Mehling 1998

Měřinský 1985

Mitáš 2015

Novotný 1966

Olexa/Nováček 2013

Pieta 2015

Pieta a i., v tlači

Profantová 2005

Přichystal 2014

Rejholcová 1995

Ruttkay 2015

Ruttkay/Ruttkayová 1998

Ruttkay/Ruttkayová 2018

Sklenář 1999

Šolle 1959

Točík $1968 a$

Točík $1968 b$

Točík 1992

Trębaczkiewicz 1963

Ungerman 2009

Váňa 1968

Vendtová 1969

Zábojník/Béreš 2016

Zeman 2016 est armis laudare. Studia dedykowane Profesorowi Potrowi Kaczanowskiemu z okazji siedemdziesiąej rocznicy urodzin. Kraków 2014, 443-453.

J. Meduna: Latènezeit. In: L. Poláček (Hrsg.): Studien zum Burgwall von Mikulčice. Band 2. Brno 1997, 249-275.

A. Mehling: Archaika als Grabbeigaben. Studien an merowingerzeitlichen Graberfeldern. Rahden/Westf. 1998.

Z. Měřínský: Velkomoravské kostrové pohřebiště ve Velkých Bílovicích. K problematice venkovských pohřebišt' 9.-10. stol. na Moravě. Praha 1985.

V. Mitáš: Keramika kultúrneho komplexu juhovýchodných popolnicových polí. In: V. Furmánek (zost.): Staré Slovensko 4. Doba bronzová. Nitra 2015, 210-223.

B. Novotný: Hromadný nález hliněných votivních symbolù ze slovanského knížecího hradu u Mikulčic. Památky archeologické 57, 1966, 649-688.

L. Olexa/T. Nováček: Pohrebisko zo staršej doby bronzovej v Nižnej Myšli. Katalóg I (hroby 1-310). Nitra 2013.

K. Pieta: Včasnostredoveké mocenské centrum Bojná - výskumy v rokoch 20072013. In: K. Pieta/Z. Robak (ed.): Bojná 2. Nové výsledky výskumu včasnostredovekých hradísk. Nitra 2015, 9-50.

K. Pieta/M. Jakubčinová/Z. Robak/T. Vangl’ová: Výskum včasnostredovekej aglomerácie Bojná v roku 2016. Archeologické výskumy a nálezy na Slovensku v roku 2016, v tlači.

N. Profantová: Analýza movitých artefaktů. In: M. Kuna/N. Profantová: Počátky raného středověku v Čechách. Praha 2005, 139-207.

A. Přichystal: Petrografické určení surovín kamenných artefaktů z raněstředověké lokality Olomouc-Nemilany. In: R. Přichystalová/M. Kalábek (ed.): Raněstředověké pohřebiště Olomouc-Nemilany. Katalog. Brno 2014, 199-201.

M. Rejholcová: Pohrebisko v Čakajovciach (9.-12. storočie). Katalóg. Nitra 1995.

M. Ruttkay: Využitie leteckej prospekcie a skenovania pri výskume hradísk a ich zázemia na západnom Slovensku. In: K. Pieta/Z. Robak (ed.): Bojná 2. Nové výsledky výskumu včasnostredovekých hradísk. Nitra 2015, 297-333.

M. Ruttkay/J. Ruttkayová: Záchranné výskumy vo Vel'kom Cetíne. Archeologické výskumy a nálezy na Slovensku v roku 1996, 1998, 141, 142.

M. Ruttkay/J. Ruttkayová: Výskum stredovekého osídlenia a pohrebiska v Nitre na Školskej ulici. Študijné zvesti AÚ SAV 64, 2018, 179-200.

K. Sklenár̆: Hromové klíny a hrnce trpaslíkü. Z pokladnice české folklórní archeologie. Praha 1999.

M. Šolle: Knížecí pohřebiště na Staré Kouřimi. Památky archeologické 50, 1959, 353-506.

A. Točík: Slawisch-awarisches Gräberfeld in Holiare. Bratislava 1968.

A. Točík: Slawisch-awarisches Gräberfeld in Štúrovo. Bratislava 1968.

A. Točík: Materiály k dejinám južného Slovenska v 7.-14. storočí. Študijné zvesti AÚ SAV 28, 1992, 5-250.

T. Trębaczkiewicz: Cmentarzysko wczesnośredniowieczne we wsi Psary, pow. Piotrkow Trybunalski. Prace i Materiały Muzeum Archeologicznego i Etnograficznego w Łodzi. Seria Archeologiczna 9. Łodz 1963, 131-166.

S. Ungerman: Archaika in den frühmittelalterlichen Gräbern in Mähren. In: P. Maříková Vlčková/J: Mlynářová/ M. Tomášek (eds.): My things changed things. Social Development and Cultural Exchange in Prehistory, Antiquity, and the Middle Ages. Praha 2009, 224-256.

Z. Váňa: Vlastislav. Výsledky výzkumu slovanského hradiště v letech 1953-55 a 1957-60. Památky archeologické 59, 1968, 5-192.

V. Vendtová: Slovanské osídlenie Pobedima a okolia. Slovenská archeológia 17, Nitra 1969, 119-232.

J. Zábojník/J. Béreš: Pohrebisko z obdobia avarského kaganátu vo Valalikoch-Všechsvätých. Nitra 2016.

T. Zeman: Miniaturní keramické nádobky z doby římské z jihovýchodní Moravy. Zborník SNM 110. Archeológia 26, 2016, 207-211. 


\title{
Finding of a prehistoric miniature vessel in the pit-house at the early medieval hillfort Valy in Bojná
}

\author{
Miri a J a ku b činová
}

\author{
Summary
}

The early medieval hillfort Valy is situated in the cadastre of Bojná in the south-western part of mountains Považský Inovec which divides Považie and Ponitrie. In the cadastre of village there are, except from the hillfort Valy, several other sites (Fig. 1). Research excavations take place on hillfort constantly since 2007, during them only part of site was explored yet (Pieta 2015, 9, 10, fig. 1). Pit-house 10 was discovered in the central part of hillfort (Fig. 2) during seasons 2015-2016. Miniature vessel (Fig. 3) was found on its bottom. Traces of handle were preserved on one side. It is probably small amphora (with one handle) or cup from the Bronze Age. Miniature vessel from Bojná, although it represents prehistoric artefact, was found in early medieval context. It is probably antiquarian artefact. These are usually found in grave as an accompanying inventory but they are discovered also on settlements or hillforts (Hanuliak 2004a; Kraskovská 1971).

Miniature ceramic vessels, although they are not widespread, we know from Slovakia (and neighbouring countries) from various time periods since Neolithic. Their precise classification is not explicit. Scientists mostly agree that these miniatures predominantly represent shapes of standard types of vessels usually used in household. To clarification of use of miniature vessel are bound different interpretations - vessels used for rituals of sacrificial uses, vessels used for storage of various spices, fats, seasonings, oils or medicaments or as a toys or products of child. It is possible to agree with T. Zeman $(2016,210)$ who states that it is impossible to develop general explanation for all miniature vessels but it is necessary to approach them individually according to certain finding content and with the help of various analyses (natural scientific or chemical).

Miniature vessel is also antiquity which doesn't represent an exceptional case on hillfort. Several artefacts were discovered during years of research we can classify to the older periods as predominant settlement of hillfort (Fig. 4; Table 1). Whole set of findings from Bojná represent basic types of archaic artefacts which we can find also in early medieval graves, vessels or their fragments also belong to them (Hanuliak 2004a; Kraskovská 1971). They are often rare subjects coming from various periods for example fragment of glass bracelet, incomplete bronze fibula, fragment of bronze arrow head or coin (Pieta 2015, 13, 14, fig. 3: 11-13). They were found mainly during lowering of layers in trenches. Part of findings was found during fieldwalking, in the filling of features or in their close distance. Mainly rare artefacts can suggest collecting activities of Slavs which could have been used again in their primary of secondary function. Summary of use and interpretation of archaic subjects was done by Š. Ungerman (2009, 238), who came out from the work of A. Mehling (1998). She divided them into four groups:

- reuse (either primary or secondary purpose);

- decoration;

- collecting artefact;

- magical properties - amulets.

Finding of miniature sparked considerations over antiquities on hillfort Valy and the need to evaluate again similar subjects from this locality. Interpretation of archaic artefacts from Bojná still remains open because research continues and also this hypothesis about collecting activities can be interpreted in different manner. Absence of ceramic material however suggests rather the fact that archaic subjects came probably from this collecting activity. It is questionable whether these subjects were discovered accidentally or they came from purposely robbed sites. However there are several important sites found near the hillfort Valy where these artefacts could have been found. 
Fig. 1. Bojná, localities in the cadastre of Bojná. Bojná I-Valy, Bojná II-Hradisko, Bojná III-Žihl’avník, Bojná IV-Mladý Háj, Bojná V-Halšiny (position of locality on map fixated by M. Bartík and E. Blažová; by Pieta 2015, fig. 1).

Fig. 2. Bojná I-Valy, pit-house 10. 1 - Ground plan of feature; 2 - view of pit-house from northwest; 3 - detail of vessel when found.

Fig. 3. Bojná I-Valy, miniature vessel (drawing by N. Vaššová, photo by M. Jakubčinová).

Fig. 4. Bojná I-Valy, localisation of individual artefacts (antiques) in area of hillfort. a - stone artefacts; b - clay artefacts; $\mathrm{c}$ - bronze artefacts; $\mathrm{d}$ - glass artefacts.

Table 1. Bojná I-Valy. List and circumstances of finding of archaic artefacts discovered at the hillfort by 2018.

Translated by Lucia Nezvalová

Mgr. Miriam Jakubčinová, PhD.

Archeologický ústav SAV

Akademická 2

SK - 94921 Nitra

miriam.jakubcinova@savba.sk 